\title{
International Organizations' Involvement in Youth Unemployment as a Global Policy Field, and the Global Financial Crisis
}

\author{
Ross Fergusson
}

\section{INTRODUCTION}

Youth employment and unemployment are only recently becoming recognized as a distinctive field of global and transnational policy. In the last two decades, several key texts have greatly deepened our understanding of International Organizations' (IOs) centrality to the governance of global social policy (notably Deacon 1997, 2007; Deacon et al. 2003; O'Brien 2014; Yeates 2000, 2014; Kaasch and Martens 2015). While all address labor or employment policy, in comparison there has been little or no analysis of global social policy actors' engagement with unemployment in relation to young people- predominantly the most vulnerable unemployment demographic in recently transformed labor markets. General interest in this policy field burgeoned in the years following the Global Financial

\footnotetext{
R. Fergusson $(\bowtie)$

Department of Social Policy and Criminology, The Open University, Milton Keynes, UK

e-mail: ross.fergusson@open.ac.uk

(C) The Author(s) 2021

K. Martens et al. (eds.), International Organizations in Global

Social Governance, Global Dynamics of Social Policy, https://doi.org/10.1007/978-3-030-65439-9_2
} 
Crisis (GFC), but it has lacked the analytical and scholarly attention to global policy afforded to other fields represented in this volume. ${ }^{1}$ As a result, understanding of how the global governance of youth (un)employment has evolved and functioned as a policy field remains comparatively limited.

This oversight could not be attributed to the short histories of IOs' activities. By far the most prominent IO in the field, the International Labour Organization (ILO) recently celebrated the centennial of its establishment under the Covenant of the League of Nations, set up by the Treaty of Versailles in 1919 to address the aftermath of World War I. The ILO's founding remit included labor relations and supply, the prevention of unemployment and other identified concerns including the protection of young people, children and women in labor markets. The only other IO of comparable historical standing, the International Bank for Reconstruction and Development (IBRD), now referred to as the World Bank (WB), was also part of an international response to catastrophic global social conflict-established as one of the Bretton Woods institutions of 1944 to prevent the recurrence of major uneven development as a widely recognized cause of World War II.

Despite the longevity and global reach and scale of the ILO and the IBRD $/ \mathrm{WB}$, their work and that of the many other IOs and the international partnerships they have initiated, it is only recently that youth unemployment (YU) is becoming collectively interpreted and analyzed as a distinctive global policy field. Perhaps more than any other single factor, it was the rapid spread of mass $\mathrm{YU}$ in many countries at unprecedented levels during and after the GFC that prompted international recognition of the fact that $\mathrm{YU}$ is a global issue and a global policy field worthy of globalist modes of analysis - most notably because of its intergenerational significance and its impacts on international labor migration and international tensions (Fergusson and Yeates 2014).

To set the contemporary context of these developments, some 'headline' data is necessary. ${ }^{2}$ Most recently, 'headcounts' of unemployed young people aged 15-24 years recorded by the ILO have been consistently

\footnotetext{
${ }^{1}$ Eichhorst and Rinne (2015), for example, estimate that by 2014,730 youth employment projects were under way in 110 countries, initiated by IOs and the international development programs of advanced economies.

${ }^{2}$ Unless otherwise stated, all YU data hereafter is drawn from ILO data to 2018 (https: $/ /$ www.ilo.org/wesodata).
} 
between $11 \%$ and $12 \%$ (1999-2019) of the labor force, peaking at 77 million worldwide in 2009, falling back to 70 million in 2015, and then rising slightly but steadily to a projected 71 million in 2018 . These data are undoubtedly significant under-counts. ${ }^{3}$ Numerically, $71 \%$ of the young people who were unemployed at the peak level in 2009 were male, $29 \%$ were female. In addition, if the category 'unemployed' is expanded to include all young people aged 15-24 years who are Not in Education, Employment or Training (NEET), this more inclusive definition of nonparticipation in labor markets rises to $22 \%$. Some data suggest that actual levels of 'registered' plus undeclared non-participation probably take the total of young people who are NEET to 130 million. If in-work poverty is included, $40 \%$ of under-25s worldwide are workless or poor (UN-ECOSOC 2016).

Rates of unemployment vary dramatically between countries and between regions. The weighted 27-year average YU rates to 2017 range between less than $5 \%$ (in ten African and Asian countries) and more than $40 \%$ (five African and three European countries). In Northern Africa, YU rates have fluctuated in the 25-35\% range since 1991; in Eastern Europe the range is 15-25\%; in Central and Western Asia 13-20\%; in Latin America and the Caribbean 10-20\%. Almost all regions have seen significant increases in these rates toward the upper range since the onset of the GFC. In South-East Asia and the Pacific five young people are unemployed for every unemployed adult. ${ }^{4}$

At these scales, for any age-range, persistently high unemployment at any spatial level cannot be construed as an economic policy problem alone: for young people, it is an acute problem for social policy. The dependency of many teenagers on their parents and other adults, the vulnerability of all young people to multiple forms of exploitation, and the harms and risks of extended periods of exclusion from labor markets and economic participation are all at high risk of becoming realized as problems of and for social policy that span multiple sectors (education, health, housing, social security) and require 'whole-society' approaches for their resolution.

Wherever possible, this chapter focuses on statutory instruments using the governance capacities of IOs. In view of the multiplicity of actors, the

\footnotetext{
${ }^{3}$ See Bardhan (1978) and Beneria (1981) on the longstanding challenges of estimating unemployment levels.

${ }^{4}$ Fergusson and Yeates (2021) provide a full analysis of the depth, extent and distribution of endemic YU.
} 
ILO's longevity as an IO, and the many forms taken by other transnational and global actors, it is necessary to concentrate analysis throughout the chapter on the ILO and WB as the two key IO actors and on the partnerships they established. Particular attention is given to the various formations these IOs constitute, and the trajectories, configurations and processes which the evolution of their partnerships has entailed. This focus emphasizes the coexistence and contestation of the ILO and WB, and the modes of mutual engagement, cooperation and collaboration between them.

As Niemann et al. (see introduction to this volume) argue, individual IOs function in contexts of coexistence, mutual recognition, cooperation, exchange, collaboration, but also in contexts of competition, contestation, struggle and conflict. The overarching predominance of the ILO and the $\mathrm{WB}$ and their partnerships epitomize these forms of coexistence. These themes should not be construed either as typical or as defining the landscape of IO actor participation in framing and embedding social policy across this field. Rather, what follows is intended to extend and diversify understanding of the forms of global social governance analyzed in this volume.

\section{Mapping the IO 'Population' and Discourses}

Six key IOs populate this policy field. They are significantly differentiated by the depth, extent and timeframes of their involvement. Perhaps predictably, the history of their engagement is a strong indicator of IOs' respective significances as effective actors: Table 2.1 indicates their influence on YU policy globally, as well as their year of first intervention.

\section{Dominant Actors: The Policy Discourses of the ILO and World Bank}

The ILO and WB have jointly established themselves as transnational authorities setting principles and standards and diffusing rules, norms and key resources in the policy field of youth (un)employment. As normentrepreneurs, in very different ways, they have identified, defined and constituted YU as a policy field, a social problem (ILO) and an economic problem (WB), assuming leading roles in producing information. Their policy discourses establish the prevailing normative and ideational 
Table 2.1 IOs in the youth unemployment policy field: earliest interventions

\begin{tabular}{|c|c|c|c|}
\hline$I O$ & Subject & Year & Notes \\
\hline $\begin{array}{l}\text { International } \\
\text { Labour } \\
\text { Organization }\end{array}$ & $\begin{array}{l}\text { Minimum age } \\
\text { conventions }\end{array}$ & 1919 & Covering a series of multiple trades \\
\hline $\begin{array}{l}\text { World Bank / } \\
\text { IBRD }\end{array}$ & $\begin{array}{l}\text { International } \\
\text { investment in } \\
\text { support of global full } \\
\text { employment }\end{array}$ & 1950 & $\begin{array}{l}\text { Commitment to act as 'the main } \\
\text { channel of international lending and } \\
\text { to bring about a stable flow of } \\
\text { international investment of major } \\
\text { dimensions' }\end{array}$ \\
\hline $\begin{array}{l}\text { UN Educational, } \\
\text { Scientific and } \\
\text { Cultural } \\
\text { Organization }\end{array}$ & $\begin{array}{l}\text { Child labor and } \\
\text { compulsory } \\
\text { education }\end{array}$ & 1951 & $\begin{array}{l}\text { Requested the ILO to prepare a } \\
\text { report for the international } \\
\text { conference on public education }\end{array}$ \\
\hline $\begin{array}{l}\text { Organisation for } \\
\text { Economic } \\
\text { Co-operation and } \\
\text { Development }\end{array}$ & $\begin{array}{l}\text { Jobs strategies for } \\
\text { member states }\end{array}$ & 1994 & $\begin{array}{l}\text { Extensive research and reporting at } \\
\text { country level regarding extremes of } \\
\text { YU }\end{array}$ \\
\hline $\begin{array}{l}\text { UN International } \\
\text { Children's } \\
\text { Emergency Fund }\end{array}$ & $\begin{array}{l}\text { Labor market } \\
\text { preparation and } \\
\text { skills-readiness for } \\
\text { under } 18 \mathrm{~s}\end{array}$ & 2005 & Data highlighting YU internationally \\
\hline $\begin{array}{l}\text { International } \\
\text { Monetary Fund }\end{array}$ & $\begin{array}{l}\text { Emergency country } \\
\text { level interventions } \\
\text { following the GFC }\end{array}$ & 2010 & $\begin{array}{l}\text { Funding in response to extreme rise } \\
\text { in YU in North Africa }\end{array}$ \\
\hline
\end{tabular}

foundations of the field, and the ILO's and WB's status as leading 'soft governance' actors.

As well as being by far the longest-standing IO, the ILO has had the most extensive engagement with youth employment and unemployment. Established in 1919 with a constitution committed to international social justice and awarded the Nobel Peace Prize in 1969, the ILO stands as an IO of unrivaled stature in the setting of international labor standards and promoting employment rights. Many of its Conventions and Recommendations bear directly on these issues with respect to YU. The ILO's interventions across the range of conventions with statutory powers, recommendations, local projects and an extensive presence on the ground across several world regions make it the pre-eminent IO globally in the field of (un)employment. The ILO works closely and interactively with other UN bodies and civil society organizations, national governments and in partnerships. 
From its inception, the ILO's discourse was focused on the need for concerted action to address the international causes of unemployment. Early work set out international norms governing young people's relationship to work and education by means of Conventions and Recommendations. Between 1919 and 2002, 48 such instruments relating to children/young people and work were crucial to the construction of this transnational policy field. For example, key instruments concerning YU during the interwar period ensured conditional financial support to the involuntarily unemployed, disputed economic theory that advocated wage reductions as a means of remedying unemployment, and stipulated compulsory general and vocational educational provision for all up to the age of 18. Many instruments have since been updated.

Since 2000, the ILO's YU policy discourse has been shaped by its Decent Work and Global Employment agendas. It has emphasized securing increases in aggregate demand for young people's labor, including by means of job creation and institutional labor market reforms, but has also advocated active labor market policies (ALMPs), selective employment incentives and supply-side labor market measures. The ILO's commitment to unemployment-related welfare benefits for young people is embedded in its discourse of 'social protection floors' that include basic income security across the life cycle. In the wake of the GFC, ILO discourse has urged member states to increase demand for young people's labor in response to 'jobless growth' and inadequate unemployment protection, while also developing more business-friendly discourses, including partnership-based entrepreneurial solutions. ILO discourses in this policy field have recently manifested increasing tensions, reconfiguring its labor market analyses and unemployment policies to concede to some neoliberal agendas, while continuing to reassert its historical commitments to international social protection and labor standards. ${ }^{5}$

In parallel with the ILO's post-WWII initiatives, the UN and IBRD were active in this field. A key UN report cites the UN's 1948 Universal Declaration of Human Rights' commitment to "the right to work, to free choice of employment, to just and favourable conditions of work and to protection against unemployment" (Article 23). The Charter of the UN pursued the threefold UN goal for "higher standards of living, full employment, and conditions of economic and social progress and development"

\footnotetext{
${ }^{5}$ See Fergusson and Yeates $(2013,2014)$ for detailed analyses of the policy discourses of all IOs reviewed here.
} 
(Article 55). The UN also called upon the IBRD to borrow from and lend to governments to facilitate full employment. While this remit drove a significant element of IBRD discourse throughout the following decades, its focus did not specifically include youth employment until the WB responded to the Millennium Development Goals (MDGs) of 2000. In collaboration with the United Nations Department of Economic and Social Affairs (UNDESA) and the ILO, the WB set up the Youth Employment Network (YEN) at the 2000 Millennium Summit. The WB's first leading intervention on $\mathrm{YU}$ followed several years later, instigating the Global Partnership for Youth Employment (GPYE) in 2008.

During the pre-GFC period the WB's interventions were largely confined to published policy positions, the discourses of which emphasized young people's insufficient or ill-matched labor market skills as a significant cause of YU. These discourses provided the rationale for the WB's criticism of regulated wages for young people, observing that $\mathrm{YU}$ rates are lowest in low-income countries, and implicitly associating this with minimal or absent minimum wage rates for young people in such economies. WB discourse also tended to attribute endemic high rates of $Y U$ to demographic bulges such that young people who could not be accommodated in labor markets should be assigned to extended schooling or vocational training. ${ }^{6}$

Two related themes connect these discourses. They are grounded in human capital theory, and all focus on supply-side interpretations of high levels of YU. As a result, WB policy advocacy has leaned strongly toward more effective job-search training, internships and measures to 'smooth' transitions into youth labor markets. However, as evidence accumulated of the prolonged effects of the GFC on YU rates (especially in Northern Africa, and also in parts of Europe in 2012-15), WB discourse adjusted, beginning with growing recognition of the damage to human development of mass $\mathrm{YU}$, its costs and its effects on public perceptions of (in) equality and social justice. The WB's recognition of multiple shortcomings of YU programs that focused on the supply-side 'deficiencies' of young labor market entrants followed. Further awareness of the high socio-economic risks of endemic mass YU (especially in politically volatile regions) intensified WB policy shifts. In parallel, the WB's earlier antiwelfare discourses abated and prompted the need to reconsider the

\footnotetext{
${ }^{6}$ See World Bank (2006, 2011, 2012); Fergusson and Yeates (2013). For a definition of endemic YU see Fergusson and Yeates (2021).
} 
boundaries of welfare, causing recognition of the need for conditional support to gain ground.

The WB's shifts in its analyses and prognoses coincided with corresponding obverse shifts in the ILO's positions, as noted above, toward some degree of convergence-thereby apparently creating the conditions for more effective dialogue and collaboration between them (see below).

\section{Other Significant Actors: UNESCO's and OECD's Policy Discourses}

From the earliest years of the UN, the United Nations Educational, Scientific and Cultural Organization (UNESCO) maintained an important role in shaping $\mathrm{YU}$ discourse as inseparable from issues of educational participation. UNESCO worked closely with the ILO and IBRD on child labor, statutory age of admission to employment and compulsory education enforcement plans (UNESCO 1951, annex II: 17). A powerful, socially progressive, discursive dynamic between UNESCO and the ILO maintained strong pro-schooling advocacy, whereby the case for reducing $\mathrm{YU}$ became bound to the case for raising the school-leaving age. Before the GFC, UNESCO discourse stressed the particular exposure of young people to the risks of economic globalization, insecure jobs, involuntarily delayed labor market entry and prolonged unemployment/underemployment (UNESCO 2004, 5). Since the GFC it has led EU-funded programs in Mediterranean Northern Africa and Western Asia. Throughout, UNESCO discourse stressed unreliable and intermittent demand for young people's labor and avoided discourses that allege poor skills and capabilities as causes of YU.

The Organisation for Economic Co-operation and Development (OECD) has been continuously active in this policy field. Its annual Employment Outlook Reports consistently address YU through in-depth multi-country strategic analyses of YU which provide extensive survey data and intensive analysis of policy effectiveness (OECD 2004-11). OECD discourses were consonant with those of the WB. They were informed by human capital theory and focused on labor market supplyside deficiencies and the reportedly ill-adapted skills of school-leavers and disincentivizing welfare programs. The GFC bore especially heavily on almost all OECD member states, triggering adjustments to OECD

\footnotetext{
${ }^{7}$ See World Bank $(2012,2013,2014,2015)$.
} 
discourse. Deficient demand for young workers became temporarily recognized as a key driver of escalating YU, and advocacy of welfare 'safety nets' for previously ineligible younger age-groups with little or no access to unemployment benefits strengthened (OECD 2010a, b, 2011a, b). Gradually, however, as continuing high YU rates were apparently becoming normalized, OECD discourse returned to young people's alleged skills deficits and the fiscally detrimental effects of subsistence-sufficient welfare benefits (OECD 2012-15). The OECD's policy discourses on YU were unusually flexible over time, while also consistently defaulting to archetypal neoliberal positions, interspersed with sporadic more social democratic leanings.

\section{Recent Entrants: UNICEF's and IMF's Policy Discourses}

Two less prominent IOs warrant recognition here. The United Nations International Children's Emergency Fund's (UNICEF) statutory focus remains on the welfare of children and young people up to age 18 under the 1989 UN Convention on the Rights of the Child, and on fighting child labor wherever appropriate. Over the long run its principal trajectory of engagement with young people's employment has been to promote and facilitate skills-related and employability programs in lower-income countries, typified by its current Generation Unlimited project supporting young people and extending its upper age-range to 24 (UNICEF 2005, 2010).

The International Monetary Fund (IMF) was a late entrant to the field. Its interventions followed escalating YU rates during the GFC. Unprecedently, the IMF's Managing Director shared public international platforms with the Director-General of the ILO, promoting discourses of social protection and labor market intervention, identifying unemployment insurance for young people as cost-effective for sustaining consumer demand, and advocating job subsidies to avoid redundancies. ${ }^{8}$

Neither UNICEF nor the IMF claim significance as defining discursive actors in this field. They are nonetheless shapers of discourses and norm-entrepreneurs in other fields, and their counter-stereotypical policy positions on YU are surprising. As a leading UN program, unaccountably, UNICEF seems to overlook the well-being of young people

\footnotetext{
${ }^{8}$ These events took place at major international conferences in Oslo (2010) and Vienna (2011).
} 
aged $15+$ and the threats to their economic and social security. Conversely, as a key Bretton Woods IO, the IMF has displayed unexpected concern for this age-group, advocating extension of social protection and job creation in the wake of the GFC and allocating major financial support to mitigate extremely high levels of YU in Northern Africa (although this appears not to be a continuous programmed intervention).

The policy discourses of these two least-influential IOs do not align well with the pro-social predispositions of UN bodies, or the pro-business predispositions of the WB and OECD. This provides a salutary reminder that the discourses and priorities of UNESCO and the OECD in this field cannot be 'read off' from their other more prominent discourses in other policy fields. It also demonstrates an ebb and flow of policy ideas and norms within IOs, which indicates ephemeral context-specific pragmatic adaptation at one extreme, or deep-rooted internal dissent at another. It is therefore salutary throughout to recall Niemann et al.'s comment (see introduction to this volume) that IOs are not monolithic discursive actors, but complex bureaucracies that experience and contain ongoing multiple sources of contestation within their organizations.

\section{Partnerships and IOs: Disseminating Knowledge, IDEAS AND DISCOURSES}

The most immediate recipients of IOs' knowledge, ideas and discourses in this policy field have been the partnerships they construct and shape as deliberate disseminators of norms and policies. It is in and through partnership that IOs have exchanged knowledge and ideas and achieved mutual recognition, sometimes leading to cooperation and collaboration in pooling resources and leveraging partners. Partnership between worldleading IOs with major resources of expertise and finance and extensive geographical and political reach offers great potential for effective intervention, while also posing considerable risks of dissent and contestation. In practice the only IOs that make continuing direct interventions in the form of specific employment projects worldwide have been the ILO and WB. Each has its own extensive network of offices worldwide, some of which commission and fund projects in places of perceived significant need according to immediate contingencies. ${ }^{9}$ Many such projects are

\footnotetext{
${ }^{9}$ In the early 2000 s, the ILO already had in place a uniquely extensive global network of up to 60 Country Offices, in Africa (14), Asia/Pacific (14), Europe and Central Asia (9), and
} 
bespoke and not necessarily part of the strategic international programs that seek to spread the priorities, knowledge and ideas IOs generate and strive to embed in national economic, employment, social and other practices. Most programs take the form of partnerships, and all but one have at least nominally been established as partnerships between the ILO and WB - typically along with one or more additional partners.

It is important to be aware of the political-economic contexts in which such partnerships evolved. Unsurprisingly, given their historical purposes, remits and priorities, the ILO and WB have extensive and sometimes contested histories regarding their political, social, and economic positions and contributions. These are captured in an academic literature too extensive to recall here. ${ }^{10}$ Very briefly summarized, one key marker of their eventual divergence and contestation can be traced back to the 1980s-90s, when the dominance of the Post-WWII UN agencies came under challenge from the Washington Consensus in response to growing international debt and the perceived need for 'structural adjustment' (particularly as a condition of WB/IMF loans), often taking the form of overt politicaleconomic attacks on social democratic values in favor of free-market and neoliberal policies. The changing political economy of global policymaking in this period challenged and partially marginalized the authority of the UN and its constituent organizations, including the ILO and its work in the field of global (un)employment. The ILO came under strong pressure to accept more flexible employment contracts and relationships, for example. It subsequently responded with a Declaration on Fundamental Principles and Rights at Work, which pledged all ILO states to uphold four 'core' labor standards, including the abolition of child labor (reiterated in 2002 through the World Commission on the Social Dimension of Globalization (ILO 2004)). ${ }^{11}$ These initiatives reasserted the ILO's standing as a norm-generating institution-although they did not extend labor rights or strengthen the enforcement of existing labor standards, and they de-emphasized statutory instruments on rights and standards in favor of

representatives in 20 more lead countries in Asia, Middle East, South America, Caribbean, Eastern Europe. The WB has in excess of 100 Country Offices that have much more diverse functions, of which tackling YU is a minor element compared to the ILO's focused network at that time.

${ }^{10}$ For example, Ghébali et al. (1989); Wallerstein (2000); Dale and Robertson (2007); Deacon $(2007,2013,2015)$; Standing (2008).

${ }^{11}$ https://www.ilo.org/declaration/lang\%2D\%2Den/index.htm. Accessed February 25,2020 . 
weaker instruments such as recommendations and codes of practice. In return - and as 'ascendant' IOs in the political-economic reconfiguration of this period - the WB (and IMF) took steps to 'regularize' their relationship with trade unions (without formalizing them), while continuing to support modes of economic development 'free' from labor regulation. ${ }^{12}$

These observations set the work of the most politically and financially engaged IOs in an altered context. The evolving development of ILO instruments alone graphically depicts its surging capacity as an agent of the global governance of social and labor policy. The great advances occurred in the decades following both World Wars, between 1919 and 1965. The countervailing watershed moment in the YU policy field was an active retreat from the values of the post-war settlement less than two decades later, making way for the period of unprecedented intensive neoliberalization outlined above, heavily promoted by the WB and IMF. The language and values of the post-war settlement were substantially over-written by IOs that extolled competition, reward of enterprise and the claimed economic and social benefits of deregulated markets in goods, services and labor. While these changes expressed themselves in complex, nuanced and sometimes contradictory ways throughout and beyond the 1980s-90s, they conditioned the practices and ambitions of many IOs and the relations between them-few more so than the ILO and WB, their work in the YU policy field and their respective mutual propensities to cooperate, coexist, diverge and later eventually to separate and create very different partnerships.

\section{Collaboration, Cooperation, Separation: Endogenous Partnership}

Inter-IO partnerships concerning YU have been a principal means by which IOs in this field have collaborated formally. The first of three ILO-WB partnerships in the cause of addressing extreme YU levels was the product of the 2000 Millennium Summit in New York. The YEN which resulted was described as a global platform to prioritize youth employment and exchange policies and programs to improve employment opportunities for youth. YEN was an archetypal semi-endogenous

\footnotetext{
${ }^{12}$ For example, the WB integrated core labor standards into some of its health-related contracts (see Yeates and Pillinger 2019). More generally, for a fuller account of tensions and advances in ILO-WB relations described here, see Deacon (2015); Fergusson and Yeates (2021).
} 
partnership of two UN IOs (ILO and UNDESA) plus a Bretton Woods institution (WB). It was managed from Geneva by the ILO, from its inception in 2004 onward. In practice, UNDESA's role was principally confined to monitoring and oversight.

The YEN network included development agencies, governments, the private sector, youth groups and non-governmental organizations (NGOs). It had a major presence in 22 lead countries including a special focus on Africa, and programs in Asia, the Middle East, South America, the Caribbean and Eastern Europe. ${ }^{13}$ The ILO's Lead Country Network collected data and prepared and implemented National Action Plans, focusing on employability, entrepreneurship, employment creation and equal opportunities. Direct financial support was confined to impact evaluations and small-scale entrepreneurship projects in Africa.

YEN prioritized awareness-raising, advocacy and capacity-building for youth organizations. It laid the groundwork for increased intergovernmental recognition that youth employment would be essential for meeting the Millennium Development Goals. Its most significant distinguishing feature was its attempt to redefine youth employment as a social development issue, rather than a labor issue. It also allowed the two leading IOs to operate and negotiate on an altered terrain that minimized the prominence of the contested elements of their non-aligned politicaleconomic positions, and to level-out their unequal strengths and powers. In practice, it was clear from the early years that YEN was shaped and defined in character with the ILO's longstanding priorities, and largely faithful to its predominant discourses. WB influence on the framing and conduct of the local projects was palpably secondary: the ILO emerged as the appropriate leading player, given its employment-focused network and its ability to work on the ground in some of the most challenging economic and political YU environments. Its pre-eminent 'street-level' reach in such contexts made it best-placed to identify the geographies of priority, based on trustworthy data and local networking with governments and pre-existing embedded programs and organizations.

An independent evaluation in the closing years of the YEN partnership reported that:

${ }^{13}$ In the early stage of its establishment, YEN was financed by a desultory cluster of national government bodies (Denmark, Sweden, UK), the International Olympic Committee and ACCENTURE PLC as well as the ILO, WB and the United Nations Industrial Development Organisation (UNIDO). 
YEN is said to have shifted course in a way that fits well with [World] Bank priorities, and as a grantee of its Global Partnership for Youth Employment (GPYE) [see below] it is seen as a good catalyst. ILO has perhaps the closest but most complex relationship with YEN, whilst UNDESA works less closely with the YEN Secretariat than the other partners, and describes its contribution as 'minimal'. (International Labour Office Evaluation Unit 2012, 4)

It is a significant and telling feature of this analysis of the work of leading IOs in this policy field that the inter-institutional and intra-institutional politics between IOs are opaque to 'remote' researchers. The closest it is possible to get to this politics is to interpret the outputs of nominally independent bodies like the ILO's Evaluation Unit. Only original primary research could provide confident insights into the closed relations within partnerships of this kind. Only tenuous deduction is therefore possible. Nonetheless, the Evaluations Unit's observation (triangulated with multiple other minor and contingent secondary indicators) strongly suggests an unequal division of labor in YEN, and some early 'sharing out' of control, as between a dominant and subordinate IO. The very conception of YEN was, self-evidently, not an untested ab initio venture, but an accretion of a wider and more ambitious structure that built on a longstanding pre-existing organizational framework-namely the ILO Lead Country Network, which was part of the ILO's employment-related work and other work in an extensive network (described above). It was this network that enabled YEN to begin new work in multiple localities barely three years after the MDGs were ratified.

The inherent dominance of the ILO in all practical aspects of managing YEN cannot reasonably be imagined as anything less than a superior degree of power, compared to that of the WB within the partnership. It is therefore less than remarkable that, in 2008, the WB instigated its GPYE, nominally incorporating YEN as one partner alongside the Arab Urban Development Institute (a not-for-profit NGO), the International Youth Foundation (IYF) (an international charitable organization) and Understanding Children's Work (an inter-agency UN body). ${ }^{14}$ The partnership focused on providing applied research and learning to better

\footnotetext{
${ }^{14}$ See ILO 2012, International Labour Conference 101st session, Committee on Youth Employment (C.E.J./D. 186). https://www.ilo.org/wcmsp5/groups/public/\%2D\%2Ded_norm $/ \% 2 \mathrm{D} \% 2 \mathrm{D}$-relconf/documents/meetingdocument/wcms_182840.pdf. Accessed March 21, 2020.
} 
understand school-to-work transitions and increase the employability of youth, promoting policy dialogue and supporting technical assistance for local governments and capacity-building for stakeholders from the public sector and civil society, to enhance their engagement-priorities that are entirely consistent with many of the WB's discourses as described above, and inconsistent with the ILO's founding discourses.

YEN's inclusion in GPYE maintained a de facto ILO presence in the partnership, for the duration of GPYE's short life. Much as the WB's early creation of GPYE gave the appearance of a successful 'take-over' bid when it 'incorporated' YEN, YEN's focus nevertheless changed under (largely direct) ILO leadership from Geneva, taking on more strategic activities through its Lead Country Network, including running YEN Networks, the youth-to-youth toolkit and monitoring and evaluation activities (ILO Evaluation Office 2018). The YEN Secretariat ceased to function in 2014 when GPYE also ceased to operate (although YEN continues as a 'brand' in ILO projects). ${ }^{15}$

YEN and GPYE constituted the decade of endogenous partnership between the pre-eminent IOs in this policy field. In all, YEN and GPYE had almost coterminous lifespans. The pressure for the ILO and WB to cooperate directly coincided with the 2001 Millennium Summit and ended in 2014. Initially, these previously often-counterposed IOs made common cause. Full cooperation in the YEN partnership nevertheless lasted little more than four years. As in all two-way partnerships (accepting that UNDESA/the United Nations Industrial Development Organization (UNIDO) were key actors only as sources of monitoring, oversight and funding), full and effective coordination depends on a single locus of governance and administration. This was initially acceded to ILO and its Geneva Offices. Primary research would be needed to provide empirical clarity about the early separation of these two dominant actors. But whatever the measures taken to ensure the WB's due influence, they were selfevidently insufficient to meet its preferences and priorities for addressing mass YU. The ILO's priorities at this time, shaped by its Global Employment Agenda, afforded strong emphasis to increasing aggregate demand for young people's labor, including by means of job creation and institutional labor market reforms, while also acknowledging some need

${ }^{15}$ By 2014, GPYE had been devolved to the IYF, which produced just two outputs. GPYE has since ceased to function. https://www.iyfnet.org/initiatives/global-partnership-youthemployment-gpye. Accessed February 25, 2020. 
for ALMPs. The WB's corresponding priorities are best encapsulated in its Social Protection and Labor (SPL) strategy (itself committed to ALMPs) and building labor market resilience in young people (WB 2011). This approach epitomizes a supply-side emphasis in addressing the challenges of mass YU. These contrasting demand-side/supply-side emphases in YU policy also epitomize the tensions that came to underlie the strategic commitments of the ILO and WB through YEN and GPYE.

YEN and GPYE had been established under the shared UN umbrella of the MDGs: MDGl included a commitment to full employment and decent work for young people. Complete severance of relations between these two leading would-be IO partners would therefore have been politically untenable. YEN continued to exist, nominally embedded within GPYE. This shifted the locus of power and funding from Geneva to Washington. However successfully the shift was mitigated by the ILO's continuing responsibility for YEN embedded within GPYE, the watershed from cooperation to coexistence en route to the separation of the ILO and WB had been crossed. Perhaps the most symbolic and informative aspects of this watershed lay in the ILO's continuing commitments to working in and through its Lead Country Networks using ILO on-the-ground infrastructure in lower-income countries, on one side of the dissolving partnership; and in the WB's enthusiasm for working with NGOs and Third Sector transnational organizations, on the other. Somewhat resonant of the distinctions between public/state versus Third Sector funding, this divergence set the stage for the next decade (and beyond) in this policy field. It was a divergence that would be based wholly on exogenous partnership and, eventually, effective separation between the lead IO partners.

\section{Coexistence, Contestation, Division: Exogenous Partnership}

GPYE was replaced by an infinitely more ambitious and very different partnership wholly led by the WB: Solutions for Youth Employment (S4YE). It is a multi-stakeholder partnership that was planned to begin in 2012 , launched in 2014 and became operational in 2015. Its high ambition to see 150 million more young people in employment is said to depend on its ability to "catalyse the promotion of public, private, and civil sector innovations". ${ }^{16}$ To date, the largest of its dozen projects across

${ }^{16}$ World Bank (2015): http://documents.worldbank.org/curated/en/76591146819 4956530/Solutions-for-youth-employment-strategic-plan-2015-2020. Accessed February 25,2020 . 
four continents has funding of just $\$ 250$ million and aims to secure employment for 500,000 young people. Described as a coalition, S4YE cultivates multiple and dynamically evolving interlocking partnershipsbuilding directly on the WB's affinity for Third Sector partnerships which it pioneered in GPYE, but moving far beyond it to embrace global corporates, and global financiers and banks. The nominal connection with the ILO continues in the form of the ILO's membership of S4YE's governing body-ostensibly largely confined to avoiding duplication and mutual conflicts of interest in work in the YU field. Alongside the IYF (itself carried over from GPYE), S4YE's original Third Sector partners include Plan International and Youth Business International (YBI), plus the RAND Corporation and Accenture. Original strategic partners include Hogan Lovells, Rockefeller Foundation, MasterCard and Ernst and Young. ${ }^{17}$

S4YE's 2015 inaugural Baseline Report commits to increasing the demand for young people's labor. From the outset, supply-side measures dominate three of the four 'Frontier Areas' of its strategic framework (S4YE 2015, 27). ${ }^{18}$ Only the 'Quality Jobs' frontier area is concerned with demand-side initiatives-generating jobs from private sector actors. No commitment is given to securing rights to social and labor protection.

In conception at least, S4YE anticipated the introduction of the UN's 2015 Sustainable Development Goals (SDGs). SDG8 prescribes the achievement of "full and productive employment and decent work for all women and men, including for young people and persons with disabilities" by 2030. ${ }^{19}$ SDG Partnerships are expected to include multistakeholder partnerships that mobilize and share knowledge, expertise, technology and financial resources.

The ILO's involvement in S4YE appeared marginal from the outset, and this was eventually confirmed by its creation of the 'Global Initiative on Decent Jobs for Youth' (GIDJY)—now the ILO's main contribution to addressing YU at program level. Launched in 2017, GIDJY also contributes to SDG8. It too is a multi-stakeholder partnership, albeit with more modest aims to train five million young people across 26 projects focused on digital skills, apprenticeships, the rural economy, green jobs,

${ }^{17}$ S4YE has since included several more global corporates, transnational Third Sector agencies and government-funded International Development Agencies among its partners.

${ }^{18}$ https://openknowledge.worldbank.org/handle/10986/23261. Accessed February 25,2020 .

${ }^{19}$ https://indicators.report/targets/8-5/. Accessed February 25, 2020. 
entrepreneurship and self-employment, transitions to the formal economy, and work in fragile settings and hazardous occupations (ILO, 2015a, 2015 b). Perhaps its most notable feature is that its 'key partners' include 11 UN IOs/agencies and exclude the WB. More than any such partnership, GIDJY epitomizes the concept of a constellation of IOs, as much founded in other IOs and other transnational UN agencies as in Third Sector and corporate partnerships. ${ }^{20}$ It places great stress on decent work, the quality of jobs for young people, promoting human rights, fostering gender equality and strengthening public-private cooperation and coherence. These characteristics sharply mark off GIDJY from S4YE's priorities and methods.

S4YE and GIDJY (now branded as Decent Jobs for Youth (DJY)) are at relatively early stages of development, with limited outcomes to date that could be viewed as commensurate with their ambitions. For the purposes of this analysis at least, more important than their most immediate achievements are their significance as unprecedented innovative partnerships which envisage hugely ambitious scope for transforming employment for young people where it is not self-generating under optimum market conditions. But in the present context of understanding the architecture of the arguments and discourses these new partnerships deploy, alongside their implications for the nature of global social governance among leading IOs, their greatest significance is already palpable. Both these new exogenous partnerships were products of endogenous partnerships that had aspired to collaboration, cooperation and modes of successful engagement in this policy field that would be greater than the achievements of the two leading IOs working separately. However, the first attempt (YEN) lasted for less than four years under its original plans. A somewhat ambiguous, low-profile, half mutually embedded partnership between the ILO and WB (GPYE) endured for approximately six more years (although, as noted, vestiges of YEN remain). The absence of transparency in the functioning of these two IOs prevents empirically sound

\footnotetext{
${ }^{20}$ GIDJY's Key Partners are the ILO, the International Trade Centre (ITC), the United Nations Capital Development Fund (UNCDF), the United Nations Conference on Trade and Development (UNCTAD) and UNIDO. Also included are multiple other UN agencies (FAO, ITU, UNHCR, UNDP, UNDESA, UNEP, UNFPA), international development agencies and charities (Citi Foundation, EYF, ITC, J-PAL, SCF, UNIAPAC, YBI), some global corporate entities (Microsoft, McDonald's, Nestle, Inter-American Development Bank), international not-for-profit organizations (AISEC, Forge), and some national government aid and ministerial bodies (Luxembourg, Netherlands, Nigeria, Spain, OIJ).
} 
analyses of the outcomes of YEN and GPYE (notwithstanding the detailed ILO Evaluation Office reports of 2012 and 2018): both IOs have been almost completely opaque as to the causes of their short-lived attempts at endogenous partnership.

Overlaying this already complex field of policy actors, in 2018 the UN's Agenda 2030 program and its Youth Strategy introduced Generation Unlimited (GenU), to ensure that every young person is in education, learning, training or employment by 2030 (in pursuit of SDG8). ${ }^{21}$ As a major global multi-sector partnership, GenU's 53-member Board includes representatives from the ILO, OECD, the European Commission and a multiplicity of UN agencies, private-sector corporate bodies, national governments, Third Sector organizations and other IOs. The World Bank and UNICEF are GenU's key IO actors (already managing a \$1 billion allocation from WB). Interestingly, UNICEF (an historically marginal contributor in this field) had displayed enthusiasm for supply-side measures, in common with the World Bank, at the start of the GFC. ${ }^{22}$ Their past shared positions (contrast ILO's and UNESCO's historical demand-side policy leanings) may well have influenced the UN's decision-making when it constituted this UNICEF-WB alliance. Certainly, the prioritization of supply-side measures is clearly evident in GenU's early on-line outputs. ${ }^{23}$ The dominant political-economic character of GenU's work 'on the ground' has yet to be revealed. However, the exclusion of the ILO from GenU's Executive, and the preponderance of global private sector and Third Sector corporates on its Board are intrinsically note-worthy (again in contrast to ILO's preference for multiple UN agencies as its key partners in S4YE). Both these observations are consistent with the paths of 'separate development' taken by the World Bank and ILO when they initiated S4YE and DJY. This prompts the question as to why the UN elected to set up a third global partnership alongside them. GenU's commitment to work across public, private and civil society sectors and governments ostensibly replicates a key premise of S4YE's approach. GenU may complement S4YE and DJY - at greatly increased scale if it achieves its ambitions - or duplicate or supersede both partnerships.

\footnotetext{
${ }^{21}$ https://www.unicef.org/young-people. Accessed June 21, 2020.

${ }^{22}$ See Fergusson and Yeates (2014).

${ }^{23}$ https://www.generationunlimited.org/news-and-stories/world-leaders-unite-education-and-training-young-people. Accessed June 21, 2020.
} 


\section{Concluding Comments}

As the key historical global actors in this field, both the ILO and WB have maintained dominant positions, in part by giving attention to opposing policy priorities, by finding some virtues in each other's dominant and normative discourses and policy logics, and sometimes by cooperating despite discursive differences. Each has endeavored to allow the other's position to stand alongside its own on some key policy dilemmas, without acceding to an opposing policy logic. Nevertheless, a highly condensed summary of their partnerships throws into stark relief the evolving trajectory of ILO-WB relations, as follows. Before the GFC, the ILO and WB coexisted and acted largely in mutual disregard, each identifiable more by their differences than by their shared objectives. With the onset of the GFC in 2008, the ILO's YEN was already weakened as a major YU platform and risked being superseded by the WB's GPYE. By 2012-13, GPYE was palpably unequal to making a significant impact on the successive waves of burgeoning YU, as the effects of the GFC unfolded internationally. Yet the ILO was then still striving to accommodate the WB's supplyside-dominated priorities, and in 2014 still accepted the role of minor IO partner in the WB's ambitious, radically innovative cross-sector S4YE 'alliance'. Scarcely a year afterward, the ILO was distancing itself from S4YE while remaining on its Board, in order to initiate DJY, and was operating with unprecedented allocations of internal funding for implementation, without assistance from the $\mathrm{WB}$, or by means of a $\mathrm{WB}$ presence on its Board.

Across nine years of the most intensive crisis of global YU in recorded history, the leading IOs moved full circle from largely mutually disregarding coexistence, through high-profile collaboration and formal partnership, to effective separation. At the point of separation, the ILO had exceptionally strong country networks and channels of local reach, and the WB retained access to extensive financial and other resources.

Understanding whether this cycle of rapid change is faithfully mirrored in both IOs' dominant policy analyses and modes of intervention in labor market and associated welfare policies requires detailed research that can only be achieved effectively by means of 'insider' access. Although much remains to be seen about the functionality and effectiveness of S4YE and DJY, the shift to exogenous partnerships embracing unprecedentedly wide and highly differentiated constellations of Third Sector/corporate partners constitutes a new mode of coexistence between the ILO and WB. This 
speaks to degrees of historical and recent contestation between them that have resulted in division into two new entities, one of which marks complete separation between the WB and ILO (DJY), the other of which retains only a nominal 'place at the table' for the ILO in a WB-defined universe (S4YE).

What also remains to be established by means of new empirical research is how far this extended history of partnership, division and separation can be attributed to the architecture of the arguments each IO deploys (along with their respective dissenting discourses); and how far it can be attributed to factors that have largely escaped the gaze of scholarship and research in this policy field. Both IOs are committed to self-evaluation, in terms of program outcomes. But their evaluations cast no light on the politics of cooperation, collaboration, coexistence and contestation between them.

To infer sources of conflict and separation from internally managed processes would be risky indeed, however strong the clues and correspondences between sources. It is clear that the balance of power and advantage between the WB and ILO has shifted significantly and more than once, in both directions, especially since the WB became fully active in the YU policy field alongside the ILO. Sometimes these shifts have matched overarching paradigm shifts, like those of the 1980s-90s. How the dynamics of change occurred and were eventually resisted within and between them cannot be 'read off' from their work in any given policy field. Equally risky would be to attempt to interpret the primary geo-political and political-economic purposes of the work of the ILO and WB from singlefield-specific contexts. The major attempts to stimulate engagement in the policy field of $\mathrm{YU}$ in the wake of the GFC also invite skeptical speculation that the principal purposes of the work of the ILO and WB were at that time to allay international concern that burgeoning YU rates posed risks well beyond their impacts on national economies-risks of civil disorder, precipitate youth labor migration, and political tensions and conflicts between semi-borderless nations. The need for the international community that funds (and seeks to influence) the ILO and WB to be 'seen to act' was compelling. Both the MDGs and SDGs placed great emphasis on (and pressures toward) partnership for development. The SDG mandates in particular spurred the efforts of the ILO and WB to act in partnership. Through S4YE and DJY, the WB and ILO nominally meet these expectations while operating separately from one another. The recent advent of GenU, however, may be intended to re-calibrate partnerships and 
relations between key players, as UNICEF is thrust into the limelight. How such separated and reconstituted partnerships operate is largely opaque to the processes of independent evaluation, especially with regard to the evolving relationships between three lead IO actors.

Arm's-length scrutiny of complex partnerships involving multiple powerful players rarely manages to deliver insights into internal intra-IO micro-politics. Even studies that gain direct access can be 'called out' on their interpretations. For example, Deacon's ground-breaking work over the last two decades has been unique and pre-eminent in the study of the dynamics of IO relations in the global governance of social policy, especially of the ILO and WB. He found numerous examples of direct dissent and struggle between them in relation to employment, social protection and other policies (Deacon 2007, 2013, 2015). But despite his longstanding, intensive and often first-hand studies, it would be rash to assume that Deacon's work has definitively explained ILO-WB dynamics. His methodology has recently been respectfully and tentatively queried for drawing premature conclusions, and for being over-reliant on accounts that reference the personal dimensions of interaction (Cichon 2019). Other policy fields also query the more critical characterizations of the WB, and re-open questions about its political-economic predispositions and stances in the 1980s-90s (see e.g. Barrientos et al. 2011; Alderman and Yemtsov 2012; Abramo et al. 2019).

The debate on the contested subject of inter-IO relations remains far from resolution. Understanding of the effects of IOs' differences, tensions and conflicts on policy outcomes also remains limited-just as knowledge of the workings of IOs' interior processes and interactions has remained commensurately limited regarding partnerships. The case for researchers to be afforded direct access to study the dynamics of key inter-IO relations is compelling. What is beyond doubt is that concerted attempts at the global governance of policies intended to alleviate continuous extremes of YU across many world regions have had ostensibly very limited impact to date. The spike in interest among most IOs in the face of the shocking scale of YU immediately after the onset of the GFC has long-since passed. Extreme youth unemployment in the Arab States, Northern Africa, Latin America/Caribbean, much of Europe and in Central and Western Asia are becoming normalized through their persistence. Among IOs, only the multi-stakeholder partnerships now operate 'on location' across these regions. 
Whether the de facto separation of the work of the ILO and WB proves more productive than their past partnerships remains to be seen. The insertion of UNICEF into the field compounds the uncertainty. As other one-time IO actors in this field fell away 'after the crisis', perhaps the question of greatest importance is whether the re-distributional powers inherent in the global social governance of youth (un)employment policy can reasonably be deemed adequate-especially in a world in which the numbers of 15-24-year-olds who are not in employment or studying or training is still estimated to substantially exceed 100 million. One certainty, though, is that the work of all three leading IOs will be severely tested by the immanent transnational effects of the SARS-Cov-2 (Covid-19) pandemic of 2020 and beyond with regard to collapsing labor markets in which young people are reliably the first victims. ${ }^{24}$

\section{REFERENCES}

Abramo, Laís, Simone Cecchini, and Beatriz Morales. 2019. Programas sociales, superación de la pobreza e inclusión laboral. Naciones Unidas: Cepal. Libros de la CEPAL, $\mathrm{N}^{\circ}$ 155. https://www.cepal.org/sites/default/files/events/files/ c1900117_web.pdf. Accessed January 13, 2020.

Alderman, Harold, and Ruslan Yemtsov. 2012. "Productive Role of Social Protection, Social Protection and Labor.” Discussion Paper \#1203, Washington: World Bank.

Bardhan, Pranab Kumar. 1978. "On Measuring Rural Unemployment." The Journal of Development Studies 14 (3): 342-352.

Barrientos, Armando, Ravi Kanbur, and Gordana Matkovic. 2011. "Statement of the Advisory Panel IEG Evaluation of World Bank Support to Social Safety Nets", 2000-2010. https://pdfs.semanticscholar.org/f3cf/7111a008aacd0f5 0c73f63200d3c96086lf7.pdf. Accessed March 25, 2020.

Beneria, Lourdes. 1981. "Conceptualizing the Labor Force: The Underestimation of Women's Economic Activities." The Journal of Development Studies, 17 (3): 10-28.

Cichon, Michael. 2019. "Bob Deacon and the Making of Sausages." Global Social Policy, 19 (1-2): 21-24.

Dale, Roger, and Susan Robertson. 2007. "New Arenas of Education Governance Reflections and Direction." In New Arenas of Education Governance. The Impact of International Organizations and Markets on Educational Policymaking, edited by Kerstin Martens, Alessandra Rusconi, and Kathrin Leuze, 217-228. Basingstoke: Palgrave Macmillan.

${ }^{24}$ For a fuller exposition see Fergusson and Yeates (2021). 
Deacon, Bob. 1997. Global Social Policy: International Organizations and the Future of Welfare. London: Sage.

Deacon, Bob, Eeva Ollila, Meri Koivusalo, and Paul Stubbs. 2003. Global Social Governance. Helsinki, Globalism and Social Policy Programme. http://praha. vupsv.cz/fulltext/ul_302.pdf. Accessed March 25, 2020.

Deacon, Bob. 2007. Global Social Policy \& Governance. London: Sage.

Deacon, Bob. 2013. Global Social Policy in the Making: The Foundations of the Social Protection Floor. Bristol: Policy Press.

Deacon, Bob. 2015. "The International Labour Organisation and Global Social Governance", in Actors and Agency in Global Social Governance, edited by Alexandra Kaasch and Kerstin Martens, 45-63. Oxford: Oxford University Press.

Eichhorst, Werner, and Ulf Rinne. 2015. "An Assessment of the Youth Employment Inventory and Implications for Germany's Development Policy" (No. 67). Bonn: Institute for the Study of Labor (IZA).

Fergusson, Ross, and Nicola Yeates. 2013. Business, as Usual: the Policy Priorities of the World Bank's Discourses on Youth Unemployment, and the Global Financial Crisis, Journal of International and Comparative Social Policy, 29 (1): 64-78.

Fergusson, Ross, and Nicola Yeates. 2014. International Governmental Organisations and Global Youth Unemployment: the Normative and Ideational Foundations of Policy Discourses, Policy \& Politics, 42 (3): 439-458. (first published online in 2013)

Fergusson, Ross, and Nicola Yeates. 2021. Global Youth Unemployment: History, Governance and Policy, Cheltenham: Edward Elgar.

Ghébali, Victor-Yves, Roberto Ago, and Nicolas Valticos. 1989. The International Labour Organisation: A case study on the evolution of UN specialised agencies (Vol. 3). Dordrecht: Martinus Nijhoff Publishers.

Independent Evaluation Group (IEG). 2013. Youth Employment Programs: An Evaluation of World Bank and International Finance Corporation Support. Washington, D.C.: World Bank.

International Labour Office Evaluation Unit. 2012. Support to the youth employment network secretariat 2010-2012: Mid-Term Evaluation. Geneva: ILO.

International Labour Organization Evaluation Office. 2018. Independent Evaluation of ILO's strategy and actions for improved youth employment prospects 2012-17. Geneva: ILO.

International Labour Organization (ILO). 2004. Conclusions of the Tripartite Meeting on Youth Employment: The Way Forward. Geneva: ILO.

International Labour Organization (ILO). 2015a. Global Initiative on Decent Jobs for Youth: The Strategy Document. Geneva: ILO. 
International Labour Organization (ILO). 2015b, 2017. Global Employment Trends for Youth report. Geneva: ILO.

Kaasch, Alexandra, and Kerstin Martens. 2015. Actors and Agency in Global Social Governance. Oxford: Oxford University Press.

O’Brien, Robert. 2014. 'Global Labour Policy', In Understanding Global Social Policy, edited by Nicola Yeates, 123-148. Bristol: Policy Press.

Organization for Economic Cooperation and Development (OECD). 2004-2015. Employment Outlook. Paris: OECD.

Organization for Economic Cooperation and Development (OECD). 2010a. Employment Outlook. Paris: OECD.

Organization for Economic Cooperation and Development (OECD). 2010b. Off to a Good Start? Jobs for Youth. Paris: OECD.

Organization for Economic Cooperation and Development (OECD). 2011 a. Secretary-General's Report to Ministers. Paris: OECD.

Organization for Economic Cooperation and Development (OECD). 2011b. Employment Outlook. Paris: OECD.

Solutions for Youth Employment (S4YE). 2015. Toward Solutions for Youth Employment: A Baseline for 2015. Washington D.C: Solutions for Youth Employment.

Standing, Guy. 2008. The ILO: An Agency for Globalization?. Development and Change, 39 (3): 355-384.

United Nations Economic and Social Council (UNECOSOC). 2016. Progress towards the sustainable development goals: report of the Secretary-General. Paris: UNESCO.

United Nations Educational, Scientific and Cultural Organisation (UNESCO). 1951. "Extension of Free and Compulsory Education," Second Regional Conference of National Commissions, WS 091/64, Paris: UNESCO.

United Nations Educational, Scientific and Cultural Organisation (UNESCO). 2004. Empowering Youth through National Policies. Paris: UNESCO.

United Nations Children's Fund. 2005. State of the World's Children 2006: Excluded and Invisible. Geneva: UNICEF.

United Nations Children's Fund. 2010. State of the World's Children 2011: Adolescence: An Age Of Opportunity. Geneva: UNICEF.

Wallerstein, Immanuel. 2000. Globalization or the age of transition? A long-term view of the trajectory of the world-system. International Sociology 15 (2): 249-265.

World Bank. 2006-2015. World development report 2007-2016. Washington, DC: World Bank. 
World Bank. 2011. Social protection and labor strategy 2012-2022: resilience, equity and opportunity. Washington DC: World Bank.

Yeates, Nicola. 2000. Globalisation and Social Policy. London: Sage.

Yeates, Nicola. 2014. Ed. Understanding Global Social Policy. Bristol: Policy Press. Yeates, Nicola, and Jane Pillinger. 2019. International Health Worker Migration and Recruitment: global governance, politics and policy. London: Routledge.

Open Access This chapter is licensed under the terms of the Creative Commons Attribution 4.0 International License (http://creativecommons.org/licenses/ by $/ 4.0 /$ ), which permits use, sharing, adaptation, distribution and reproduction in any medium or format, as long as you give appropriate credit to the original author(s) and the source, provide a link to the Creative Commons licence and indicate if changes were made.

The images or other third party material in this chapter are included in the chapter's Creative Commons licence, unless indicated otherwise in a credit line to the material. If material is not included in the chapter's Creative Commons licence and your intended use is not permitted by statutory regulation or exceeds the permitted use, you will need to obtain permission directly from the copyright holder.

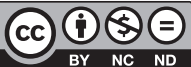

